\title{
Effects of dietary protein concentration on growth and muscle composition of juvenile Zacco barbata
}

\author{
Wen-Jiunn Shyong a,b, Chen-Huei Huang ${ }^{\text {a, * }}$, Hon-Cheng Chen ${ }^{b}$ \\ ${ }^{a}$ Department of Aquaculture, National Chiayi Institute of Technology, Chiayi, Taiwan \\ ${ }^{\mathrm{b}}$ Department of Zoology, National Taiwan University, Taipei, Taiwan
}

Accepted 22 June 1998

\begin{abstract}
The effects of dietary protein concentration on growth and muscle composition of juvenile Zacco barbata were investigated using white fish meal as the major protein source. Six experimental moist diets containing 20.5 to $45.3 \%$ protein were fed to triplicate groups of 16 fishes $(0.338 \pm 0.002 \mathrm{~g})$ for 10 weeks. There was no mortality among test fishes throughout the experiment. Specific growth rates and feed conversion ratios for fish fed diets containing 30.7, $35.2,40.9$, and $45.3 \%$ protein were better $(P<0.05)$ than those fed diets containing 20.5 and $25.8 \%$ protein. Fish fed $35.2,40.9$, and $45.3 \%$ protein diets excreted more $(P<0.05)$ ammonia than fish fed diets containing 20.5 and $25.8 \%$ protein. Fish on the lowest protein diet $(20.5 \%)$ showed the highest protein efficiency ratio. Fish fed high-protein diets had higher protein and ash content in their muscle. Whereas, fish fed high-protein diets had lower lipid content in muscle than those fed low-protein diets. Analyzed by a broken-line model with final body weight as the indicator, the optimal dietary protein level for Z. barbata is approximately $32.0 \pm 0.1 \%$. (C) 1998 Published by Elsevier Science B.V. All rights reserved.
\end{abstract}

Keywords: Dietary protein concentration; Muscle composition; Zacco barbata; Optimal protein requirement; Ammonia excretion

\section{Introduction}

Zacco barbata is an endemic freshwater fish that is widely distributed in the mountain streams of western Taiwan (Shen et al., 1993). In recent years, the culture of

\footnotetext{
* Corresponding author. Tel.: + 886-5-2766141 ext. 502; Fax: + 886-5-2751704; E-mail: chuhuang@ rice.cit.edu.tw
} 
this fish species has been expanding due to an increasing demand from consumers, especially tourists from urban areas. Studies on Z. barbata have concentrated on reproductive biology and breeding behavior (Chuang and Lin, 1995; Yan et al., 1995). Little nutritional information is available for this species. Fish farmers have been using various commercial feeds to raise this fish. Among them, commercial eel feeds with protein content of $45 \%$ or higher are the most widely used feeds for culture of $Z$. barbata in fish farms.

It is well known that the protein content of diets should be maintained at a suitable level to minimize feed costs. Besides, when dietary protein level exceeds the requirement, the fish excretes more ammonia nitrogen into the surrounding environment (Cai and Summerfelt, 1992; Buttle et al., 1995; Cai et al., 1996; Tidwell et al., 1996), thus reducing the quality of the culture water. Growth of the fish also might be affected since extra energy is required to deaminate the excess amino acids absorbed (Jauncey, 1982). On the contrary, a protein-deficient diet results in reduced growth of the fish (Brecka et al., 1995; Shiau and Lan, 1996; Huang and Shyong, 1998).

The objective of this study was to investigate the growth performance, muscle composition, and ammonia excretion of $Z$. barbata fed different levels of dietary protein. The optimal dietary protein level for this fish species also was estimated.

\section{Materials and methods}

Six isocaloric test diets were prepared to contain $3810 \mathrm{kcal}$ metabolizable energy $(\mathrm{ME}) / \mathrm{kg}$ and levels of protein ranging from 20.5 (diet A) to $45.3 \%$ (diet F) by increments of $5 \%$ (Table 1). The ME values were calculated using the physiological fuel values of $4 \mathrm{kcal} / \mathrm{g}$ for carbohydrate and protein and $9 \mathrm{kcal} / \mathrm{g}$ for lipid (Maynard and Loosli, 1969). This level of ME was selected because the energy of $3700 \mathrm{kcal} / \mathrm{kg}$ was good for the growth of another fish species grown in the same habitat (Huang and Shyong, 1998). The major protein source was white fish meal obtained from Fleshier Fishing, New Zealand. Commercial aquacultural premixes of vitamins and minerals were purchased from Taiwan Cyanamid.

For the sake of good palatability and protein quality, white fish meal was used as the protein source in this study. The feed ingredients were crushed by a hammer mill, passed through a 35-mesh screen, and mixed in a KitchenAid heavy duty mixer. Menhaden fish oil were added to the feed mixtures at the final mixing stage. The resulting powdered diets were stored at $-40^{\circ} \mathrm{C}$ in a laboratory freezer until the time of feeding.

Juvenile Z. barbata, hatched in our laboratory, were raised in a 500-1 fiber glass tank prior to the experiment. A commercial feed (Tung Bao, Tainan, Taiwan) was used to acclimate the fish to the laboratory conditions 2 weeks before the experiment. Proximate composition of the commercial diet was as follows: moisture, 11.5\%; crude protein, 40.8\%; crude lipid, 3.7\%; crude fiber, 2.7\%; ash, $15.3 \%$. After the acclimation, fish were selected and randomly assigned into 18 glass aquaria $(45 \mathrm{~L} \times 30 \mathrm{~W} \times 30 \mathrm{H} \mathrm{cm})$ at a stocking density of 16 fish each. Three aquaria, randomly arranged, were assigned to each of the test diets. Mean initial body weight of fishes was $0.338 \pm 0.002 \mathrm{~g}$ for all 
Table 1

Diet formula and proximate analysis of the experimental diets $(\%)$

\begin{tabular}{|c|c|c|c|c|c|c|}
\hline & A & B & $\mathrm{C}$ & $\mathrm{D}$ & $\mathrm{E}$ & $\mathrm{F}$ \\
\hline \multicolumn{7}{|l|}{ Ingredient } \\
\hline Fish meal & 24 & 33 & 42 & 51 & 60 & 69 \\
\hline Corn meal & 48.4 & 39.4 & 31.4 & 22.4 & 15.4 & 6.4 \\
\hline Menhaden fish oil & 7 & 7 & 6 & 6 & 5 & 5 \\
\hline$\alpha$-starch & 20 & 20 & 20 & 20 & 20 & 20 \\
\hline Calcium phosphate & 0.2 & 0.2 & 0.2 & 0.2 & 0.2 & 0.2 \\
\hline Vitamin premix ${ }^{a}$ & 0.2 & 0.2 & 0.2 & 0.2 & 0.2 & 0.2 \\
\hline Mineral premix ${ }^{b}$ & 0.2 & 0.2 & 0.2 & 0.2 & 0.2 & 0.2 \\
\hline \multicolumn{7}{|c|}{ Analyzed nutrient content } \\
\hline Moisture & 7.1 & 7.5 & 7.0 & 6.5 & 7.3 & 6.9 \\
\hline Crude protein & 20.5 & 25.8 & 30.7 & 35.2 & 40.9 & 45.3 \\
\hline Crude lipids & 7.6 & 7.7 & 8.8 & 8.3 & 9.5 & 9.9 \\
\hline Crude fiber & 1.5 & 1.2 & 1.2 & 0.9 & 0.8 & 0.5 \\
\hline Ash & 4.3 & 5.5 & 6.9 & 7.9 & 9.2 & 10.1 \\
\hline $\mathrm{NFE}^{\mathrm{c}}$ & 59.0 & 52.3 & 46.4 & 42.2 & 33.5 & 28.3 \\
\hline ME (kcal/kg diet) & 3860 & 3820 & 3840 & 3800 & 3780 & 3800 \\
\hline
\end{tabular}

${ }^{\mathrm{a} O n e-k g}$ vitamin premix contained 2,000,000 IU retinol, 400,000 IU vitamin $\mathrm{D}_{3}, 20 \mathrm{~g} \alpha$-tocopherol, $2 \mathrm{~g}$ vitamin $\mathrm{K}_{3}, 2 \mathrm{~g}$ thiamin, $5 \mathrm{~g}$ riboflavin, $2 \mathrm{~g}$ vitamin $\mathrm{B}_{6}, 0.01 \mathrm{~g}$ vitamin $\mathrm{B}_{12}, 10 \mathrm{~g}$ pantothenic acid, $15 \mathrm{~g}$ niacin, $0.5 \mathrm{~g}$ folic acid, $50 \mathrm{~g}$ choline chloride, $50 \mathrm{~g}$ ascorbic acid, and $20 \mathrm{~g}$ inositol.

${ }^{\mathrm{b}}$ One-kg mineral premix contained $70 \mathrm{~g}$ manganese, $10 \mathrm{~g}$ copper, $100 \mathrm{~g}$ iron, $80 \mathrm{~g}$ zinc, $1 \mathrm{~g}$ iodine, and $50 \mathrm{~g}$ choline chloride.

${ }^{\mathrm{c}} \mathrm{NFE}$ was calculated by difference.

treatments. Each aquarium containing 301 of freshwater was continuously aerated by an air stone. All aquaria were cleaned daily in the afternoon by siphoning off accumulated waste materials. Approximately 101 of water in each aquarium was replaced with aerated freshwater daily. Water temperature, dissolved oxygen, $\mathrm{pH}$, and total hardness of the water were monitored every week. Water temperature was kept between 24 and $26^{\circ} \mathrm{C}$ throughout the experiment; dissolved oxygen ranged from 6.0 to $7.6 \mathrm{mg} / 1$; $\mathrm{pH}$ values ranged from 8.19 to 8.56 ; total hardness ranged from 153 to $160 \mathrm{mg} / \mathrm{kg}$.

The experimental fish were fed $6 \%$ of their body weight daily. This amount was close to the maximum daily ration consumed by juvenile $Z$. barbata during the acclimation period. Immediately before feeding, the powdered feeds were mixed with equal weights of water to form ball shape moist paste diets. Moist test diets were fed to fish once daily at 9 AM for 10 weeks. All fish in the aquaria were individually weighed every 2 weeks. The amounts of feeds supplied to test fish were adjusted every 2 weeks according to the results of body weight measurement.

At $24 \mathrm{~h}$ after the last feeding, two fish from each aquarium were taken for ammonia excretion determination. Each fish was placed in a 500-ml BOD bottle and kept in a dark room for $4 \mathrm{~h}$ at $26^{\circ} \mathrm{C}$. The ammonia content in the bottle was measured at the beginning and the end of the 4-h period using the indophenol blue method (Solorzano, 1969). The measurement of ammonia excretion was made $24 \mathrm{~h}$ after the last feeding because the variation of values was stable for fish on the same diet group at this stage 
(Shu, 1995). This measurement also served as a good indicator for dietary protein adequacy for Varicorhinus barbatulus (Huang and Shyong, 1998).

At the end of the experiment, eight fish were sampled randomly from each aquarium. The muscles were carefully scratched off the fish, pooled, and ground. Diets and fish muscles were analyzed in triplicate for their proximate composition. Moisture, crude protein, crude fiber, and ash were determined following methods of the Association of Official Analytical Chemists (A.O.A.C., 1984). Crude protein was determined by Kjeldhal procedure using Kjeltec System from Tecator, Sweden. Crude lipid was extracted using the method of Folch et al. (1957).

All data were analyzed statistically by analysis of variance (Steele and Torrie, 1960) using SigmaStat statistical software from SPSS. Tukey's multiple comparison test was used to evaluate the mean difference among individual diets at the 0.05 significance level. The broken-line regression model was used to estimate the dietary protein requirement of juvenile $Z$. barbata (Robbins et al., 1979).

\section{Results}

Specific growth rate (SGR), feed conversion ratio (FCR), and protein efficiency ratio (PER) of the test fish could be divided into two groups according to the statistical significance, fish with dietary protein equal to or less than $25.8 \%$ and those fed dietary protein equal to or more than $30.7 \%$ (Table 2). Fish fed diets containing 20.5 and $25.8 \%$ protein had significantly lower SGR than those fed high dietary protein diets $(P<0.05)$. The values of FCR for fish fed diets containing protein equal to or greater than $30.7 \%$ were significantly lower than fish fed 20.5 and $25.8 \%$ protein diets $(P<0.05)$. Data of PER for test fish could not be easily separated into two groups as SGR and FCR did. However, clearly PER decreased when dietary protein level increased.

Muscle moisture contents were the same for fish fed diets containing 20.5 to $45.3 \%$ dietary protein $(P>0.05$, Table 3$)$. However, the muscle protein, lipid, and ash were influenced by the dietary protein level. Muscle protein contents increased significantly when dietary protein levels increased. Whereas, the muscle lipid content was low for

Table 2

Percentage weight gain, SGR, FCR and PER of Z. barbata fed experimental diets for 10 weeks $^{1}$

\begin{tabular}{|c|c|c|c|c|c|c|}
\hline & \multicolumn{6}{|c|}{ Dietary protein $(\%)$} \\
\hline & 20.5 & 25.8 & 30.7 & 35.2 & 40.9 & 45.3 \\
\hline $\mathrm{SGR}^{2}$ & $1.55 \pm 0.04^{\mathrm{a}}$ & $1.74 \pm 0.04^{\mathrm{a}}$ & $2.06 \pm 0.02^{b}$ & $2.11 \pm 0.05^{b}$ & $2.11 \pm 0.06^{\mathrm{b}}$ & $2.13 \pm 0.10^{b}$ \\
\hline $\mathrm{FCR}^{3}$ & $3.37 \pm 0.08^{\mathrm{a}}$ & $2.97 \pm 0.08^{\mathrm{b}}$ & $2.44 \pm 0.02^{\mathrm{c}}$ & $2.46 \pm 0.07^{\mathrm{c}}$ & $2.40 \pm 0.05^{\mathrm{c}}$ & $2.53 \pm 0.13^{c}$ \\
\hline $\mathrm{PER}^{4}$ & $1.34 \pm 0.04^{\mathrm{a}}$ & $1.21 \pm 0.03^{\mathrm{ab}}$ & $1.24 \pm 0.01^{\mathrm{ab}}$ & $1.08 \pm 0.03^{b c}$ & $0.95 \pm 0.02^{\mathrm{c}}$ & $0.83 \pm 0.05^{\mathrm{c}}$ \\
\hline
\end{tabular}

\footnotetext{
${ }^{1}$ Within each row, means $( \pm$ S.E. $)$ with different superscript letters are significantly different $(P<0.05)$.

${ }^{2} \operatorname{SGR}(\% /$ day $)=100[\ln ($ final body weight $)-\ln ($ initial body weight $)] /$ feeding days.

${ }^{3} \mathrm{FCR}=$ dry feed intake/wet weight gain.

${ }^{4} \mathrm{PER}=$ wet weight gain/protein intake.
} 
Table 3

Composition of muscle (\%) from Z. barbata fed experimental diets for 10 weeks ${ }^{1,2}$

\begin{tabular}{|c|c|c|c|c|c|c|}
\hline & \multicolumn{6}{|c|}{ Dietary protein $(\%)$} \\
\hline & 20.5 & 25.8 & 30.7 & 35.2 & 40.9 & 45.3 \\
\hline Moisture & $74.0 \pm 0.1^{\mathrm{a}}$ & $73.2 \pm 0.4^{\mathrm{a}}$ & $74.4 \pm 0.1^{\mathrm{a}}$ & $73.8 \pm 0.2^{\mathrm{a}}$ & $74.0 \pm 0.1^{\mathrm{a}}$ & $73.7 \pm 0.5^{\mathrm{a}}$ \\
\hline Crude protein & $19.8 \pm 0.5^{\mathrm{b}}$ & $20.3 \pm 0.3^{\mathrm{ab}}$ & $20.2 \pm 0.3^{\mathrm{ab}}$ & $21.0 \pm 0.2^{\mathrm{ab}}$ & $21.7 \pm 0.6^{\mathrm{a}}$ & $21.9 \pm 0.4^{\mathrm{a}}$ \\
\hline Crude lipid & $4.4 \pm 0.1^{\mathrm{ab}}$ & $4.7 \pm 0.1^{\mathrm{a}}$ & $4.6 \pm 0.4^{\mathrm{a}}$ & $4.0 \pm 0.2^{\mathrm{ab}}$ & $4.0 \pm 0.1^{\mathrm{ab}}$ & $3.5 \pm 0.1^{\mathrm{b}}$ \\
\hline Ash & $2.1 \pm 0.03^{\mathrm{cd}}$ & $2.2 \pm 0.07^{\mathrm{bcd}}$ & $1.9 \pm 0.02^{\mathrm{d}}$ & $2.3 \pm 0.07^{\mathrm{bc}}$ & $2.5 \pm 0.08^{\mathrm{ab}}$ & $2.7 \pm 0.05^{\mathrm{a}}$ \\
\hline
\end{tabular}

${ }^{1}$ Initial fish muscle contained $74.0 \%$ moisture, $20.1 \%$ protein, $4.3 \%$ lipids, and $2.1 \%$ ash.

${ }^{2}$ Within each row, means $( \pm$ S.E. $)$ with different superscript letters are significantly different $(P<0.05)$.

fish fed high-protein diets. Fish fed the diet containing $45.3 \%$ protein had highest ash content in muscle.

Protein levels in diets significantly influenced the amount of ammonia excreted from test fish. The amounts of ammonia excreted by fishes fed 35.2, 40.9 and $45.3 \%$ protein diets were $30.1,30.1$, and $35.2 \mathrm{mg} \mathrm{kg}^{-1} \mathrm{~h}^{-1}$, respectively. These values were significantly $(P<0.05)$ higher than those from fish fed 20.5 and $25.8 \%$ protein diets. They excreted 23.1 and $23.4 \mathrm{mg} \mathrm{kg}^{-1} \mathrm{~h}^{-1}$ ammonia.

Final mean body weights were $1.00,1.14,1.43,1.48,1.49$, and $1.51 \mathrm{~g}$ for fish fed $20.5,25.8,30.7,35.2,40.9$, and $45.3 \%$ dietary protein, respectively. Using final body

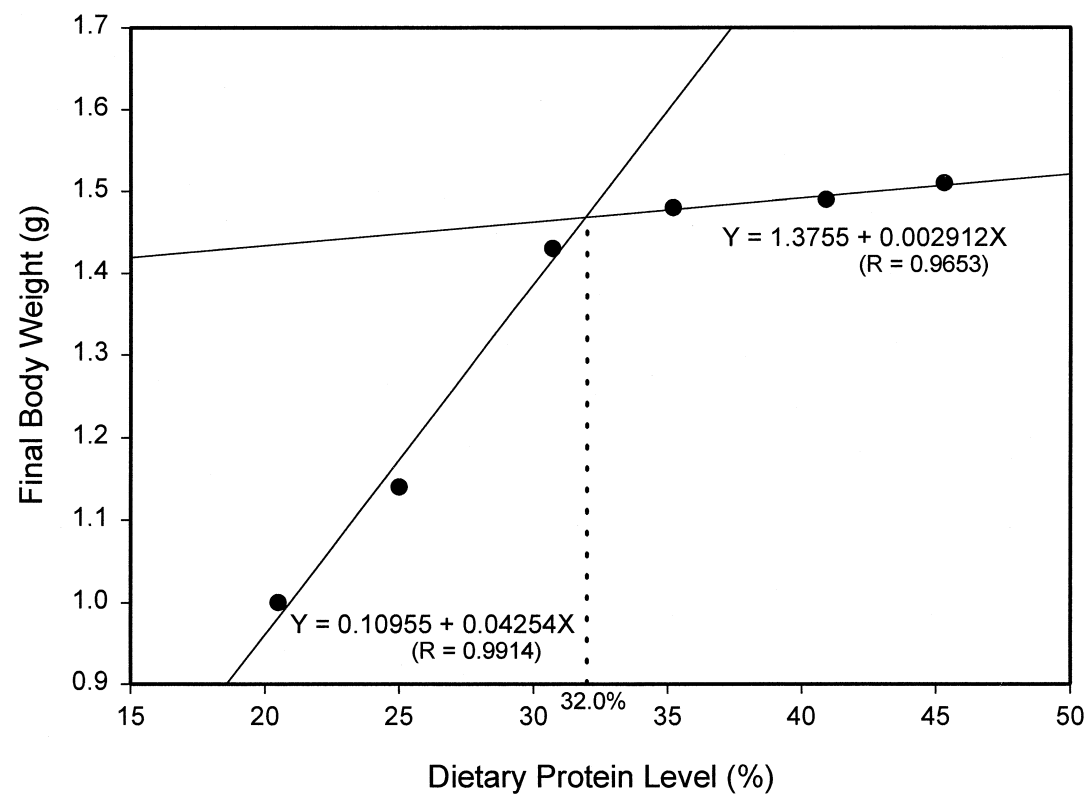

Fig. 1. The effect of dietary protein level on growth of Z. barbata. Each point represents the means of three groups of fish, with 16 fishes per group. The dietary protein requirement for $Z$. barbata is approximately $32.0 \pm 0.1 \%$ when analyzed by a broken-line model. 
weights as the indicator, and analyzed by a broken-line model, to estimate the optimal dietary protein level for juvenile $Z$. barbata as shown in Fig. 1, the regression equations were $Y=0.10955+0.04254 X$ and $Y=1.3755+0.002912 X$. The dietary protein requirement of juvenile $Z$. barbata was estimated to be $32.0 \pm 0.1 \%$ since this was the break point that gave the least mean square error.

\section{Discussion}

From the results of this experiment, we observed that the indicators of growth performance such as SGR and FCR of juvenile Z. barbata improved when dietary protein concentration increased. However, the values of these indicators leveled off when dietary protein concentration reached $30 \%$. This means that the optimum dietary protein level is about $30 \%$. Above this level of protein, growth was similar and without significant difference among diets containing 30.7 to $45.3 \%$ protein. The FCR values in Table 2 were likely to be higher than the true FCR because we did not take into account the feed lost in the water. The test fish were fed moist paste diets in this study because of better palatability. Although the diets were consumed withing $15 \mathrm{~min}$, the loss of feed into the surrounding water was unavoidable. In this study, we assumed that the loss of feed was proportionally the same for all test diets.

Opposite to the above indicators, fish fed low-protein diets had higher PER than those fed high-protein diets. The results of high PER values at low dietary protein level has also been observed in carp (Ogino and Saito, 1970), grass carp (Dabrowski, 1977), silver carp (Singh, 1990), Cirrhinus mrigala fry (Das and Ray, 1991), gilthead sea bream (Santinha et al., 1996), and V. barbatulus (Huang and Shyong, 1998). This observation has been suggested to be due to high utilization of dietary protein as an energy source, especially when high-protein diets were fed to the fish (Kim et al., 1991; Santinha et al., 1996). In the present study, with 20.5 and $25.8 \%$ protein diets, fish did not have enough protein and showed significantly lower growth than the other fish. On the other hand, with diets containing 30.7 to $45.3 \%$ protein, fish had enough protein for their maximum growth. Meanwhile, with high availability of protein, the fish used a high percentage of protein to obtain energy in relation to fish fed less dietary protein. As a result, the PER of test fish decreased when dietary protein increased. This also resulted in the high ammonia excretion for fish on high-protein diets.

The concentration of dietary protein had profound effect on muscle composition of fish. There was a significant increase in muscle protein content with increasing dietary protein level. Similarly, fish fed high-protein diets tended to have lower muscle lipid contents and higher ash contents. Similar results of dietary protein on carcass composition has been observed in other studies with common carp (Zeitter et al., 1984), plaice (Cowey et al., 1972), and snakehead fry (Mohanty and Samantaray, 1996). Nose and Arai (1972), however, found that carcass lipid content in Japanese eel increased when dietary protein level increased.

Ammonia excretion has been suggested as an indicator of dietary protein adequacy (Cai et al., 1996). Fish consuming dietary protein in excess to their requirements are expected to excrete significantly more ammonia than those consuming inadequate 
protein. Our data on ammonia excretion suggests that dietary protein levels of 20.5 and $25.8 \%$ were inadequate for juvenile $Z$. barbata. This was in accordance with the growth performance data. Based on the results of ammonia excretion and growth performance data, the minimum dietary protein level to achieve maximum growth for juvenile $Z$. barbata was about $30 \%$ under our experimental conditions. The estimated dietary protein requirement was $32.0 \pm 0.1 \%$ for $Z$. barbata when analyzed by the broken-line model using final body weight as the indicator. This was quite close to the dietary protein requirement of $V$. barbatulus, a fish species grown in the same habitat as $Z$. barbata. The dietary protein requirement for V. barbatulus ranged from 29 to $35 \%$.

\section{Acknowledgements}

The funding of this work was provided in part by the Council of Agriculture (AST-1.12FID-07) and the National Science Council (NSC 87-2313-B-021-013), the Republic of China. We thank Ms. W.Y. Lin for technical assistance. Thanks also to Dr. S.-Y. Shiau for his valuable suggestions during the preparation of the manuscript.

\section{References}

A.O.A.C., 1984. Official Methods of Analysis of the Association of Official Analytical Chemists, 14th edn. AOAC, Arlington, VA.

Brecka, B.J., Kohler, C.C., Wahl, D.H., 1995. Effects of dietary protein concentration on growth, survival, and body composition of muskellunge Esox masquinongy and tiger muskellunge Esox masquinongy $\times$ E. lucius fingerlings. J. World Aquacult. Soc. 26, 416-425.

Buttle, L.G., Uglow, R.F., Cowx, I.G., 1995. Effect of dietary protein on the nitrogen excretion and growth of the African catfish, Clarias gariepinus. Aquat. Living Resour. 8, 407-414.

Cai, Y., Summerfelt, R.C., 1992. Effects of temperature and size on oxygen consumption and ammonia excretion by walleye. Aquaculture 104, 127-138.

Cai, Y., Wermerskirchen, J., Adelman, I., 1996. Ammonia excretion rate indicates dietary protein adequacy for fish. Prog. Fish-Cult. 58, 124-127.

Chuang, L.C., Lin, Y.S., 1995. Notes on the breeding behavior of Zacco barbata. Acta Zool. Taiwanica 6, 91-94.

Cowey, C.B., Pope, J.A., Andron, J.W., Blair, A., 1972. Studies on the nutrition of marine flatfish, The protein requirements of plaice, Pleuronectes platessa. Br. J. Nutr. 28, 447-456.

Dabrowski, K., 1977. Protein requirement of grass carp (Ctenopharyngodon idella Val.). Aquaculture 12, $63-73$.

Das, I., Ray, A.K., 1991. Growth response and feed conversion efficiency in Cirrhinus mrigala (Ham.) fingerlings at varying protein levels. J. Aqua. Trop. 6, 179-185.

Folch, J., Lees, M., Stanley, C.H.S., 1957. A simple method for the isolation and purification of total lipids from animal tissue. J. Biol. Chem. 226, 497-509.

Huang, C.H., Shyong, W.J., 1998. Effect of dietary protein levels on growth of Varicorhinus barbatulus. Chin. Biosci. 41, 1-10.

Jauncey, K., 1982. The effect of varying dietary protein level on the growth, food conversion, protein utilization and body composition of juvenile tilapia, Sarotherodon mosambicus. Aquaculture 27, 43-54.

Kim, K., Kayes, T.B., Amundson, C.H., 1991. Purified diet development and re-evaluation of the dietary protein requirement of fingerling rainbow trout (Oncorhynchus mykiss). Aquaculture 96, 57-67.

Maynard, L.A., Loosli, J.K., 1969. Animal Nutrition, McGraw-Hill, New York. 
Mohanty, S.S., Samantaray, K., 1996. Effect of varying levels of dietary protein on the growth performance and feed conversion efficiency of snakehead, Channa striata fry. Aquacult. Nutr. 2, 89-94.

Nose, T., Arai, S., 1972. Optimal level of protein in purified diet for eel, Anguilla japonica. Bull. Freshwat. Fish. Res. Lab. 22, 145-155.

Ogino, C., Saito, K., 1970. Protein nutrition in fish: I. The utilization of dietary protein by young carp. Bull. Jpn. Soc. Sci. Fish. 36, 250-254.

Robbins, K.R., Norton, H.W., Baker, D.H., 1979. Estimation of nutrient requirements from growth data. J. Nutr. 109, 1710-1714.

Santinha, P.J.M., Gomes, E.F.S., Coimbra, J.O., 1996. Effects of protein level of the diet on digestibility and growth of gilthead sea bream, Sparus auratus L. Aquacult. Nutr. 2, 81-87.

Shen, S.C., Lee, S.C., Shao, K.T., Mok, C.H., Chen, C.C., Tzeng, C.S., 1993. Fishes of Taiwan, Department of Zoology, National Taiwan University, Taipei.

Shiau, S.-Y., Lan, C.-W., 1996. Optimum dietary protein level and protein to energy ratio for growth of grouper (Epinephelus malabaricus). Aquaculture 145, 259-266.

Shu, W.C., 1995. Effects of dietary protein source, protein/energy ratio and carbohydrate/fat ratio on growth of Japanese eel (Anguilla japonica). Master Thesis, National Taiwan Ocean University, Keelung.

Singh, B.N., 1990. Protein requirement of young silver carp, Hypophthalmichthys molitrix (Val.). J. Freshwat. Biol. 2, 89-95.

Solorzano, L., 1969. Determination of ammonia in natural water by the phenol-hypochloride method. Limn. Oceanogr. 14, 799-801.

Steele, R.G.D., Torrie, J.H., 1960. Principles and Procedures of Statistics, McGraw-Hill, New York.

Tidwell, J.H., Webster, C.D., Coyle, S.D., 1996. Effects of dietary protein level on second year growth and water quality for largemouth bass (Micropterus salmoides) raised in ponds. Aquaculture 145, 213-223.

Yan, J.H., Lue, K.Y., Chen, Y.S., Jeng, J.K., 1995. The study on the reproductive ecology of Zacco barbata in Ha-Pen creek. Biol. Bull. Natl. Taiwan Normal Univ. 30, 69-81.

Zeitter, M., Kirchgessner, M., Schwarz, F.J., 1984. Effects of different protein and energy supplies on carcass composition of carp, Cyprinus carpio (L.). Aquaculture 36, 37-48. 